\title{
THE AIRLINE INDUSTRY IN 2050
}

DATA PRZESŁANIA:12.12.2015 | DATA AKCEPTACJI:12.12.2015|JEL CODE: 032

\section{PhD, Ing. Tomasz Balcerzak}

Faculty of Transport, Silesian University of Technology, Krasińskiego 13, 40-019 Katowice, Poland.

e-mail: tomasz.balcerzak@polsl.pl in 2050. It includes a description of the global economy, its impact on the civil aviation, describes future customers and air passengers, their preferences, expectations and priorities. There is also a description of future technological solutions implemented in planes, their design, engines, technical capabilities and equipment. The article focuses on the impact of air transport on the environment and other related sectors of the aviation sector.

KEYWORDS innovation, transport policy, aviation policy, airport, future of the aircraft

\section{INTRODUCTION}

In the past 40 years the volume of air travel has expanded tenfold and air freight has grown by a factor of fourteen. The world's economies have grown three to four times over the same period. Air transport has been one of the world's fastest growing economic sectors.

Travel markets do mature, and many of the OECD (Organization for Economic Cooperation and Development) markets have seen growth slow. But there is still huge untapped potential to provide air transport services connecting the growing megacities and populations of the BRICs - a grouping acronym that refers to the countries of Brazil, Russia, India and China. The center of gravity of the industry is shifting eastward. In these regions the demand for air transport is set to expand substantially over the coming decades.

In meeting this demand the industry has benefited from airframe and engine technology improvements that have doubled fuel efficiency in the past 40 years. Airline have also substantially raised asset utilization and delivered large productivity improvements for all their major inputs. The unit cost of air transport has more than halved over this period as a result. 
Utilization and productivity gains were driven by changing business models and substantially increased competition, as liberalized market access became widespread over this period and many new airlines entered the industry. This has been a tremendous benefit to the consumer. Virtually all of the reductions in unit costs over this period has been passed on through a halving of the real cost to consumers of air travel and air cargo.

By contrast the shareholders of airlines over this period have seen no return to compensate them for their risk taking. Over the past 40 years the net post-tax profit of the airline industry worldwide has averaged a paltry $0.1 \%$ of revenues. There are a small number of airlines that do consistently generate a return on capital that exceeds its cost. They include airlines small and large, LCCs (low cost carriers), full-service network and regional airlines, and can be found in all the major regions. There is no simple, obvious reason for their success compared with the persistent poor profits of the majority of the industry.

Suppliers and other industries in the air transport value chain do generate sufficient profits to pay investors a normal return, in some cases with returns on capital well into double figures. Airlines stand out in the value chain as earning the lowest returns and bearing virtually the highest risk. However, the most profitable sectors in the value chain are relatively small compared to the capital invested in the airlines.

There is today over 500 billion dollars of investors' capital tied up in the airline industry. In a 'normal' industry investors would earn at least the cost of capital, implying a return of 40 billion dollars a year. In fact, over the past decade investors have seen their capital earn 20 billion dollars a year less than it would have invested elsewhere. Even at the top of the last cycle over 9 billion dollars of investor value was destroyed.

According to IATA (IATA Vision..., 2011) - International Air Transport Association, there is Five Forces framework to illuminate the reasons why airline profitability is so poor; through the forces of rivalry, new entrants, customer and supplier bargaining power, and the threat of substitutes. There are few industries where all five forces act so strongly to depress profitability as they do in the airline industry.

Rivalry is intense, driven by a perishable product, difficulty in sustaining product differentiation, high fixed and low marginal costs, high exit barriers, capacity that can only be increased stepwise, and volatile markets.

The threat of new entrants is also high. Over 1,300 new airlines were established in the past 40 years. Barriers to entry are low as market access is increasingly liberalized, economies of scale in operations are limited, access to distribution channels is easy and consumer switching costs are low.

Moreover, the bargaining power of customers is high and rising. Channels have become significantly more concentrated, travel agents more aggressive in pursuing the interests of end corporate customers, a significant share of end customers is highly price sensitive and for whom the impact of loyalty programs is limited.

The bargaining power for suppliers of several critical airline inputs is high. As a group, suppliers earn higher returns than their cost of capital, and returns are significantly higher than those for airlines. Manufacturing is a highly concentrated oligopoly, labor unions have been powerful in a number of airlines, many airports and ground handling companies are local monopolies.

The most powerful substitute to air travel is the decision not to travel, particularly for leisure travel. The threat of other substitutes has also started to become more significant in some segments, with high-speed trains, private jets and the improvement in video conferencing technology. 
The Five Forces analysis reveals the deep underlying challenges facing airline profitability. Some other industry share similar product, industry and market features but nonetheless generate returns for their shareholders. The reason why the airline industry differs lies in government policies, strategic choices by airlines and the behavior of suppliers.

The nature of government intervention is a key reason for poor airline profitability. Restrictions on cross-border investments, the nature of bankruptcy procedures, and subsidies for failing airlines are some of the key barriers that keep the industry from adopting a more effective structure.

A number of airline strategy choices appear individually rational but in aggregate contribute to a market environment that is worse for everyone. Competition is too often on size and network breadth, rather than on differentiation. Supplier behavior creates further challenges.

Does poor airline profitability matter? Regulators will only care if there are societal costs. When airlines are forced into bankruptcy, there clearly are major costs. Fragmentation is also costly. The benefits of greater consolidation in terms of reduced congestion, emissions and efficiency have been substantial.

There are a number of lessons. Artificial barriers to exit and consolidation need to be removed. Artificial incentives for entry and capacity expansion also need to be addressed. Airlines need to change (but not reduce) the way they compete. Unnecessary system costs must be reduced through policy change and better coordination.

Moving to action requires the airline industry to invest in coherently documenting the benefits it provides in the global economy. For the change to happen, the industry efforts must be framed as a campaign to reduce the societal costs of poor industry structure. All recommendations need to be supported by documenting the benefits for each stakeholder asked to act. The action agenda should build on the positive trends already under way, and needs to be communicated by the airline industry through one voice. To build momentum, initial focus should be on steps that can be taken by IATA, individual companies or more enlightened countries.

\section{THE WORLD IN 2050}

The global population has grown from 6.9 billion to 8.9 billion in the past 40 years. But birth rates in general, and particularly in the developed world, have continued to decline over the same period and radical new healthcare technologies have resulted in the average life expectancy in the developed world increasing to 99 years.

The global economy has also seen reasonably steady growth over the past 40 years, with the GDP - Gross Domestic Product of the G20 countries increasing from 38 trillion dollars in 2009 to 170 trillion dollars today. China became the world's largest economy just over the last 15 years and today China, India, Brazil, Russia and Mexico account for just over $50 \%$ of the GDP of the G20 countries. Indonesia, the Philippines, Vietnam, Iran, Turkey, Chile, and South Africa are not far behind.

New technology has revolutionized the way that people live their lives. Access to information in real time at any time of the day and anywhere on the planet is now a more widely held expectation. Virtually all people manage their lives using Lifestyle Integrated Management Pods (LIMPs), which are small portable devices containing all necessary personal data related to their owners. All LIMPs are allocated at birth and managed by parents until individuals reach 16 years of age.

LIMPs incorporate a real-time link to the Internet, the global integrated communications and lifestyle management matrix. Through LIMPs, individuals can manage literally every part 
of their lives, including all communications, entertainment, business, commercial and information needs. They contain all bio-metric data and allow individuals to constantly monitor their own health and, to a certain extent, fix health problems that arise. They incorporate a means of contacting every other person on the planet that has their own LIMP. They facilitate the buying, selling and shipping of goods from any point to any destination and the ability to know precisely where those goods are every second of their journey. They provide a single portal for accessing all desired forms of electronic entertainment, including the ability to spend time in custom-designed or community-based virtual reality "lifestyles". They also provide access to information, including audio/video coverage, in real time of virtually every event that is taking place anywhere on the planet at any time.

Both economic development and technological advances have changed the shape of global geopolitics for the better. After the turbulent period between 2010 and 2030, when tensions relating to ethnicity, religious beliefs and natural resources threatened to become unmanageable, global geopolitics have become generally more stable. Economic development in different parts of the world has most often resulted in greater economic parity amongst states, although the distinction between developed and developing still exists, and technology advances have facilitated real-time diplomacy. However, tensions between different states still exist over a number of issues. For example, concerns over fresh-water supplies are a cause of some tension even though $80 \%$ of the population now derives $80 \%$ of its drinking water from desalination plants. In addition, there are still disillusioned non-state-sponsored groups that are inclined to use violence to further their causes.

\section{THE AIRLINE INDUSTRY IN 2050}

An industry that carried 2.4 billion passengers and shipped 40 million tons of goods in 2010, carried 16 billion passengers and shipped 400 million tons of goods this year. Air transport has grown at almost twice the rate of GDP expansion, meaning that more people travel than ever before and more frequently than ever before. Global advances in general technology have been mirrored in the airline industry, which has made the sector unrecognizable from what it was in 2035. Traveling by air is faster (when desired), safer and more seamless than ever before.

Unsurprisingly, mobile technology available to air transport consumers is also affecting their behavior when they travel. LIMPs mean that they have the ability to effortlessly and seamlessly change itineraries as and when they see fit. Passenger information and transfer offices are a thing of the past. And fortunately so are queues. In-flight entertainment systems are also no longer present on most aircraft, because passengers have all of their personal audio, video or virtual entertainment needs to hand and available to take on board, downloaded directly from the Internet, which automatically charges them the correct amount.

Vastly improved high-speed train networks are now the norm in developed economies. As such, the train is often the preferred alternative for journeys of fewer than 500 miles. But for customers wishing to travel longer distances, air travel remains the only option available.

The shipment of cargo has been equally revolutionized. Businesses rarely have corporate centers anymore and manufacturers move their operations from one site to another with increasing regularity as labor and raw materials are more easily available anywhere and at any time. So as with passengers, cargo operators have had to evolve their operations based on the need for ever-increasing flexibility and customization. Individuals with shipping needs have also come to enjoy the benefits of greater flexibility and customization. 


\section{WHO ARE AIRLINE CUSTOMERS IN 2050?}

The general aging of the world population has resulted in airline customers being on average older than ever before. However, healthcare advances mean that even though our customers are older, they are not necessarily less mobile.

Younger travelers are significantly more aware of air travel and more worldly-wise than previous generations. Many are frequent fliers by the time they have learned to talk. As a result, most 4-5-year-olds have already established preferences about air travel, including brand loyalty. Historically, as children become adolescents, their tastes and values relating to many parts of their lives change. In 2050, and because of their extensive experience of air travel by the time they reach adolescence, such changes in preference are mirrored when it comes to air travel. This shift now provides new opportunities for companies to generate brand loyalty amongst a new generation of travelers.

Younger travelers are also much more technologically advanced than ever before. They have never known a world in which virtual reality was not present, and thus even have difficulty imagining a world in which it is not possible to control or at least influence one's own reality. They also take for granted the speed with which communication is possible and the sheer volume of communication taking place. This demand for technology is central to every aspect of their lives.

Increased access to advanced communications tools and the widespread use of social media have resulted in individuals and businesses having increasing networks of global friends or business contacts. But no technology has been able to replace the human-to-human contact facilitated by air travel.

Forty years ago the industry's two largest markets were still the United States and Europe. But this has not been the case for a long time. The shift eastward started early in the century supported by strong growth in China and India. When Indians started traveling with the same propensity as North Americans, that market alone jumped to four billion passengers. A similar leap has already happened in the likes of Brazil, Russia, and Mexico. It is starting to happen with Indonesia, the Philippines, Vietnam, Iran, Turkey, Chile, and South Africa. The result is an increasingly socially, culturally, and ethnically diverse pool of customers, with increasingly diverse demands based on their culture, social background, or ethnicity that wish to visit an increasingly diverse range of destinations. In turn, operators have made their product offerings equally diverse to cater to such an array of demands. This has been best achieved by the truly global operators with highly developed loyalty programs.

Increased access to information has also led to our customers being better informed than ever before. And better informed customers are more demanding customers.

\section{WHAT ARE AIRLINE CUSTOMERS' PRIORITIES IN 2050?}

In 2050, safety and security are still top priorities for passengers, but the increasingly rare nature of safety and security incidents means that these priorities are less frequently reinforced. Safety in particular is less of a concern, as automation and new technology have continued to revolutionize safety standards. The same technology has meant that reliability is also something that plays a decreasing role in consumer choice, given that flights are almost always on time and are almost never cancelled. There are still sporadic security threats regarding air transport, but these threats have gradually decreased over the past 40 years, again due in most part to technological advances that have improved the screening and tracking of passengers and cargo. 
Price is still a key driver of consumer choice, but access to information has made price transparency almost absolute, which has made price differences between comparable products almost extinct. As such, price has become more of a driver when choosing between different product types, and operators have learned to offer a wider array of products to cater to every need. Whether distinguishing between business and leisure travelers, or between older and younger travelers, today pricing is more reflective of what has become the most precious of commodities.

Business people still value their time above all else and are therefore willing to pay a premium for the fastest available transport options. Amongst leisure passengers, technological advances and the elimination of security, customs and immigration delays have fuelled a large increase in the demand for international and cross-cultural travel.

Older travelers seek greater comfort and convenience, as well as a slower pace or travel. As pension ages have steadily climbed, some retirees have had to become more price conscious than others, but many view the journey as a part of the experience as opposed to just a means of getting to their final destination. And for this they are prepared to pay extra.

For pre-adolescent travelers, priorities have not changed substantially over the past 40 years. The method and the medium may have changed, but these consumers still basically just want to be entertained. Many air carriers have already moved away from investing in in-flight entertainment systems because the majority of pre-adolescents have all of the entertainment they need on their LIMPs.

For adolescents, entertainment is also still a high priority, but entertainment that is more about being social than individual. Some operators now offer "adolescent only" sections on their larger aircraft, to enable adolescents the opportunity to meet, play games, and even establish friendships with people of their own age. For these adolescents, this is continuing the shift away from air travel just being a means of getting to their destination; it is making the travel itself an important part of the whole trip.

This trend is also the case for young adults, as more and more operators offer the opportunity for them to use their journey to meet and socialize with members of the opposite sex. This has become particularly popular amongst young adults who are traveling in a group, as they are now able to 'get the party started' on the aircraft instead of having to wait until they reach their destination.

Customers from what used to be called developing economies are trying air transport services for the first time in ever-increasing numbers. Often their first trips are for VFR - Visual Flight Rules purposes, but rising living standards normally lead them into the tourism market, some faster than others. These customers tend to seek the lowest cost transport options. The nearly ubiquitous presence of news and information from around the world makes these passengers more cosmopolitan than their counterparts from developed countries a half-century earlier and, as a result, turns them into international travelers more quickly than ever before.

Those customers from developed economies demand more and more authenticity and customization. For them, just traveling by air is not enough, they want a personal and unique experience. Having visited every continent and scores of different countries, these passengers are increasingly looking for something 'extra', something 'special'. Week-long "Aircations" (cruises in the sky) have become popular. Space travel is becoming more reasonably priced, although stays in "Spatels" (space hotels) are still reserved for the relatively well off and week-long stays in Space Spas are only for the truly wealthy.

One demand that has become consistently high among every type of traveler is customer service. With almost no price differentials between comparable products, operators have been 
forced to achieve ever greater levels of customer service. In fact, customer service has become effectively 'atomized', from mass, to niche, to the individual. Customer surveys have demonstrated that, even though competition is fierce and the difference between customer service levels are minimal, even minimal differences pay dividends to the operators that get customer service right.

Ethical consumerism continues to be a growing trend. Once upon a time, environmental concerns had an increasing influence over consumer choices. Whilst aviation's contribution to climate change has been largely addressed, this kind of ethical consumerism was the start of the trend that now focuses on such issues as the preservation of local cultures and livelihoods. In addition, with widespread economic development across the planet the definition of "rights" has been expanded to include things like annual vacations and minimum lifestyle standards.

\section{CHANGES IN AIRCRAFT CONFIGURATION}

Compared to 2010, the difference in technology most visible to the eye is in aircraft configuration. While the tube and wing configuration had been dominant in civil aviation from the inception of the jet age, two other configurations have now come to the fore. The first of these incorporates a "double bubble" fuselage cross-section configuration, so named because the fuselage is basically two tubes side by side. The second is a "blended wing body", an aircraft with a triangular hybrid wing body, made possible by advanced composites technology that blends into efficient supercritical wings.

The double-bubble was initially targeted at the B737 or A320 aircraft size, and it has been very effective in that market, offering not only fuel burn advantages, but also decreased runway length and the ability to use smaller airports. The aircraft fuselage is shorter and wider than that of a 737, with two parallel tubes in the fuselage, which allow two aisles, a time saver for passenger loading and unloading. The aircraft flies roughly $10 \%$ slower than the 737 so the wings require less sweepback. The lower speed also allows other changes that result in a lighter, more efficient aircraft.

The hybrid wing body offers large volume for a given aircraft size, and was initially introduced for cargo application. The performance of this configuration scales better for a large aircraft size and it has also appeared as a large-scale, long-range passenger aircraft, accommodating over 400 passengers in a multi-class configuration with cargo, and a range of at least 7,000 nautical miles.

Both configurations have innovative engine placements that offer substantial reductions in fuel burn due to their ability to ingest and energize the slowly moving air near the fuselage, a process which is inherently more fuel efficient than podded inlets. The double-bubble configuration has three engines, placed above the aircraft, between the vertical tails, providing shielding from engine noise, and the hybrid wing body has embedded engines at the rear of the fuselage.

Surface contours, coatings and flow-control devices have aided aerodynamic efficiency, including laminar flow for sections of fuselage/wing/nacelles to reduce drag. Electronics has been integrated into the designs of new materials, enabling "intelligent" materials to continuously monitor their state of health, so maintenance needs are automatically predicted and the work scheduled well in advance. Electro-mechanics have largely replaced traditional hydraulic/ pneumatics.

Supersonic aircraft are also in use for special applications, such as business jets where speed is the traveler's priority, but they do not have the same level of market presence of the above two configurations. 


\section{IMPROVED EFFICIENCY ENGINES AND ENGINE ARCHITECTURES}

Engine specific fuel consumption has improved by $30 \%$ since 2010 . High-performance ceramics and improved flow designs are in wide usage, including the high-efficiency, small core components that are implied by the large increases in fan bypass ratio and the major decreases in aircraft drag. The engine on-wing-time has been extended to be comparable with the useful life of the aircraft, through greater reliability. Modular designs have improved maintenance and reduced upgrade expense. Geared turbofans are now widespread, and open rotor designs are also seen. In addition, the pace of efficiency improvements has resulted in many more operators renewing their fleets more regularly to ensure that they are always using the latest, most-efficient technology. With older aircraft less in demand, due to the competitive disadvantages of operating them, a large aircraft recycling industry has emerged and reduced the overall cost of aircraft production while also overcoming shortages in scarce input materials, such as titanium.

\section{THE AIRCRAFT ARE DIFFERENT ON THE INSIDE AS WELL AS ON THE OUTSIDE}

Nanotechnology has revolutionized materials to allow new optimized structures that are half the weight they were 40 years ago. Transparency-on-demand structures negate the need for windows, with open-skies views from the flight deck and passenger areas, at reduced weight and cost, providing 360-degree views. Aircraft are now 'self supporting', eliminating most ground-support equipment, greatly cutting ramp operations.

Plant-based fiber products are also being used to drive weight savings and increase opportunities to recycle. Virtually all aircraft interior materials are now made of recycled components. Cabin interiors are also lightweight and 'self freshening' so they always appear to be new, thanks to nanotechnology. Such technologies have also been applied to ovens, trash compactors, toilets, and water systems.

Aircraft are rarely now fitted with in-flight entertainment systems; passengers bring on board their own personal devices that seamlessly interface with firewalled aircraft data systems, which act as a gateway to the 2050 "data cloud". Flight deck automation and self-optimizing "smart systems" enable the pilot to act as flight manager most of the time. Keeping current on flight controls skills is the biggest driver to 'hand flying' time and most training is done in simulators.

\section{HOW QUIET/CLEAN CAN AIRLINE BUSINESS GO?}

As mentioned, LTO (Landing-Take off cycle) oxides of nitrogen $\left(\mathrm{NO}_{\mathrm{x}}\right)$ have been cut by $75 \%$ since 2010. Carbon dioxide $\left(\mathrm{CO}_{2}\right)$ has been reduced proportionally to improvements in fuel efficiency. Carbon monoxide (CO) emissions have all but disappeared. Noise control technology is now integrated during the design phase, not as an 'add-on', with aircraft quieter than road/train traffic around airports. 'Active' noise control allows quiet zones to be created for special mitigation of noise. However, there is a growing concern about a new type of pollution - "visual pollution" resulting from the sheer number of aircraft in operation. 


\section{AIRLINE MARKET STILL NEEDS ENERGY DENSE, LIQUID HYDROCARBON FUEL}

The Earth's crude oil reserves have become more expensive and more difficult to extract, not just from a technical viewpoint but also politically. Fortunately, synthetic fuel is now widely available and widely used in all modes of transportation vehicles. A wide variety of feedstock types are used to create high-quality 'drop-in' fuels. Bio-content in aviation fuel has become increasingly commonplace over the past 40 years and currently accounts for $80 \%$ of all commercial aviation jet fuel as traditional jet kerosene is slowly phased out. A key feature in this has been an emphasis on biofuels with major lifecycle carbon benefits. This, coupled with the aircraft and engine improvements, means an effective reduction in total aviation $\mathrm{CO}_{2}$ emissions to substantially less than half of pre-2005 levels, even though air traffic has greatly increased. A continued emphasis on 'ethical consumption' has made carbon offsetting the norm for passengers, as in other aspects of their lives, thereby further reducing aviation's total net carbon emissions.

Some aircraft systems are now partially powered by solar sources that enhance the onboard "smart hybrid" electrical grid. The majority of batteries and power generators have been replaced by fuel cells that use hydrogen, plus oxygen from the atmosphere, to make electricity. Tests are also currently under way to examine how nanotechnology could be used in the design and manufacturing of the next generation of solar cells and batteries, which would in turn be even more energy efficient than today.

\section{INCREASED AIRCRAFT OPERATING CAPABILITY FROM INFORMATION SHARING}

By switching from (legacy) ground-based systems to satellite-based network information sharing and navigation, pilots and controllers have been provided with a common and complete situational picture, giving both more precise control and also increased flexibility. This has also enabled relief in the workload of air traffic controllers and increased the airspace capacity by reducing separation minimums and allowing for more direct routes. Advances in automation have enabled further efficiencies through automatically controlled aircraft. While these could produce pilotless aircraft through the application of Unmanned Aerial Vehicle (UAV) technologies, such aircraft are currently only used for all-cargo operations.

The enhanced information sharing, which has allowed in-flight aircraft to reduce their separation margins and even fly in formation much as birds do, is also driving further energy savings. As a related benefit, runway capacities have been enhanced by innovative procedures for reducing the effects of wake vortices on following aircraft. Also the trend towards use of secondary airports, which can offload traffic from heavily used primary aircraft, in a multi-airport metroplex system around major metropolitan areas has increased.

\section{OTHER AVIATION BUSINESS}

Technology has made the security and customs/immigration processes for passenger and luggage screening not only more efficient but also almost invisible to the passenger. These processes are now partially completed well in advance of the passenger journey through profiling that categorizes passengers and packages by levels of potential risk. The remaining processes are conducted using stand-off technologies that complete the screening processes without interrupting 
the passenger's journey through the airport (except for when these stand-off technologies reveal the need for closer inspection).

Technology has also been applied to passengers and their luggage. PDAs - Personal Digital Assistant and other hand-held or worn devices now enable passengers themselves to track their luggage at every stage of a journey, virtually eliminating the problem of mishandled baggage. Following the emergence of a new business model in the 2020s, companies now provide overnight door-to-door pick-up and delivery of baggage at surprisingly low cost, thereby relieving the passenger of this burden and making the airport process for the passenger far more efficient. Meanwhile, these same PDAs/other similar devices allow airlines, airports, and security agencies to track the whereabouts of the passengers themselves throughout the journey, ensuring that passengers no longer accidentally miss their flights.

\section{CONCLUSION}

A decade of change has transformed aviation. Airlines are leaner, greener, safer and stronger.

The industry had also grown to meet the needs of a globalizing world. Compared to 2001, freight shipments expanded by 17 million tons to 46 million annually. At the same time, air travel became accessible to a billion more travelers a year and we expect 2.8 billion people to fly in 2011 .

The decade also saw industry revenues double to an expected 598 billion dollars. But industry profits are much less impressive. Over the last 40 years, the average net margin is $0.1 \%$. And even in the best year of the last decade - 2010 - the industry's 18 billion dollars profit is equal to a pathetic margin of just $3.2 \%$, that does not cover the $7-8 \%$ cost of capital.

Looking ahead, we can see that in 2050 aviation will fly 16 billion passengers and 400 million tons of cargo. We must be able to manage that with sustainable technologies and efficient infrastructure, while pleasing our passengers and rewarding our shareholders. At the 2010 IATA Annual General Meeting has been announced Vision 2050 with these principles as cornerstones.

Vision 2050 did not identify a silver bullet to secure a more successful future. The papers that follow highlight the need for ongoing change.

Firstly, airline industry should break down the silos that dominate the industry's value chain. This will allow for a rebalancing of financial reward to reflect the risk taken. By working together as a united industry, it can create new value propositions for customers and move away from destructive competition based solely on price.

Secondly, airline industry must challenge governments to join in change. This means replacing interventionist micro-management and punitive taxation as the modus operandi of many, with a positive approach based on a level playing field and focused on commercial freedoms.

Thirdly, airline industry must embrace the reality of an industry whose center of gravity is shifting away from our traditional leaders in the US and Europe. Asia-Pacific is already the biggest market. The continued development of China and India will keep this region at the industry's forefront. Airline industry must engage the region to deliver leadership for change.

The last decade has shown that by working together within airline industry with a common purpose, change is possible. Vision 2050 is not a roadmap to the future. Flexibility and openness to change will mark the way forward. Instead, Vision 2050 is a challenge to all aviation stakeholders - to unite in articulating and delivering a dynamic vision of wonderful aviation industry's future. 


\section{REFERENCES}

Adler, N., Yazhemsky, E. (2009). Improving discrimination in Data Envelopment Analysis: PCA-DEA versus Variable Reduction. Which method at what cost? European Journal of Operational Research, 01/2010, 202 (1).

Airbus. Global Market Forecast 2014-2033. Available at: http://www.airbusgroup.com/dam/assets/airbusgroup/int/en/investor-relations/documents/2014/Publications/presentations/Airbus-GMF-booklet-2014-2033/Airbus\%20GMF\%20booklet\%202014-2033.pdf.

Alford, E., Champley, R. (2007). The impact of the 2007 U.S.-EU Open Skies Air Transport Agreement, ITA Occasional Paper no. 07-001.

Barros, C.P., Sampaio, A. (2004). Technical and Allocative Efficiency in Airports. International Journal of Transport Economics, 31, p. 355-377; Brattle Group. (2002). The impact of an EU-US Open Aviation Area, London and Washington.

Bruning, E.R. (1991). Market liberalization and operating efficiency in the international aviation industry. International Journal of Transport Economics, 18 (3), p. 259-274.

Charnes, A., Cooper, W.W., Rhodes, E. (1978). Measuring the efficiency of decision making units. European Journal of Operational Research, 2, p. 429-444.

Cieśla, M., Bogacki, A. (2014). „Wprowadzenie innowacji w zakresie obsługi pasażerów przez agenta handlingowego w Międzynarodowym Porcie Lotniczym Katowice-Pyrzowice". [In Polish: "The introduction of innovation in passenger service by the handling agent in Katowice-Pyrzowice International Airport"]. Prace Naukowe Politechniki Warszawskiej - Transport 103, p. 25-34. ISSN 1230-9265.

Cooper, W.W., Seiford, L.M., Tone, K. (2000). Data Envelopment Analysis: A Comprehensive Text with Models, Applications, References and DEA-Solver Software, Kluwer Academic Publisher, p. 12-150.

Current Market Outlook 2014-2033, Boeing, 2015.

Doganis, R. (1992). The Airport Business, Routledge, London and New York. ELFAA (European Low Fares Airline Association); Liberalization of European Air Transport: the Benefits of Low Fares Airlines to Consumers, Airports, Regions and the Environment. (2009). Brussels.

EASA. General Aviation Roadmap: towards simpler, lighter, better rules for General Aviation. Available at: http://easa.europa.eu/easa-and-you/general-aviation/general-aviation-road-map.

European Commission. Aeronautics and Air Transport Research: 7th Framework Programme 2007-2013. Project Synopses. Volume 3. Available at:www.ec.europa.eu/transport/modes/air/consultations/ doc/2015-aviation-package/ background.pdf.

European Commission. Flightpath 2050: Europe's Vision for Aviation. Available at: www.ec.europa.eu/ transport/modes/air/consultations/doc/2015-aviation-package/ background.pdf.

European Commission. Public consultation on the EU Aviation Package: Background information. Available at: www.ec.europa.eu/transport/modes/air/consultations/doc/2015-aviation-package/ background.pdf.

European Commission. (2014). Understand the policy of the European Union: Transport. Luksemburg: Publications Office of the European Union. ISBN 978-92-79-42790-9.

Europejski Trybunał Obrachunkowy. Infrastruktura portów lotniczych współfinansowana ze środków UE: znikome korzyści w stosunku do kosztów. [The European Court of Auditors. Airport infrastructure co-financed by EU funds: poor value for the cost].

Farrell, M.J. (1957). The measurement of productive efficiency. J.R. Statis. Soc. Series A 120, p. 253-261.

Fernandes, E., Pacheco, R.R. (2002). Efficient use of airport capacity, Transportation Research Part A, 36 (3), p. 225-238.

Fethi, M.D., Jackson, P.M., Weyman-Jones, T.G. (2001). European airlines: a stochastic dea study of efficiency with market liberalization. https://dspace.lboro.ac.uk/2134/420.

Forsyth, P., King J., Rodolfo, C. (2006). Open Skies in ASEAN, Journal of Air Transport Management, 12, p. 143-152. 
Francis, G., Fidato, A., Humphreys, I. (2003). Airport-airline interaction: the impact of low-cost carriers on two European airports. Journal of Air Transport Management, 9, p. 267-273.

Franke, M. (2004). Competition between network carriers and low-cost carriers - retreat battle or breakthrough to a new level of efficiency? Journal of Air Transport Management, 10, p. 15-21.

Gillen, D., Lall, A. (2004). Competitive advantage of low-cost carriers: some implications for airports. Journal of Air Transport Management, 10, p. 41-50.

Graham, A., Holvad, T. (2000). Efficiency Measurement for Airports, TrafikDags PAA Aalborg Universitet 2000 Conference, Aalborg University.

http://ec.europa.eu/research/transport/pdf/project_synopses_en.pdf.

http://ec.europa.eu/transport/modes/air/doc/flightpath2050.pdf.

http://www.iata.org/pressroom/facts_figures/fact_sheets/Documents/fact-sheet-industry-facts.pdf.

IATA. FACT SHEET: Industry Statistics.

IATA Vision 2050, Report, Singapore 12 February 2011.

Komisja Europejska. „Komunikat Komisji do Parlamentu Europejskiego, Rady, Europejskiego Komitetu Ekonomiczno-Społecznego i Komitetu Regionów: Program prac Komisji na 2015 r. Nowy początek”. [European Commission. "Communication from the Commission to the European Parliament, the Council, the European Economic and Social Committee and the Committee of the Regions: The Commission work program for 2015. A new beginning"].

Komisja Europejska. „Komunikat Komisji do Parlamentu Europejskiego, Rady: Nowa era w dziejach lotnictwa. Otwarcie rynku lotniczego na cywilne wykorzystanie systemów zdalnie pilotowanych statków powietrznych w bezpieczny i zrównoważony sposób". [European Commission. "Communication from the Commission to the European Parliament, the Council: A new era in the history of aviation Open air market on the civilian use of systems remotely piloted aircraft in a safe and sustainable manner"].

Laprus, K. (2010). Rynek lotniczy na świecie, Kraków [Available at: http://wtir.awf. krakow.pl/pdf/studenci/strony_st/projekty/branzowe/2010\%20Laprus\%20Krzysztof\%20Rynek\%20lotniczy\%20na\%20 swiecie.pdf].

Lin, L.C., Hong, C.H. (2006). Operational performance evaluation of international major airports: An application of data envelopment analysis. Journal of Air Transport Management, 12, p. 342-351.

Martin, J.C., Roman, C. (2001). An application of DEA to measure the efficiency of 79 Spanish airports prior to privatization. Journal of Air Transport Management, 7, p. 149-157.

Matusiak, K. (2011). Innowacje i transfer technologii. Słownik pojęć. [In Polish: Innovation and technology transfer. Glossary]. Warszawa: PARP, Wyd. III. ISBN: 978-83-7633-164-5.

Müller, J., Ülkü, T., Živanović, J. (2009). Privatization, restructuring and its effects on performance: A comparison between German and British airports, Paper No. 2, Date: 04/2009, German Airport Performance. Available at: http://www.gap-projekt.de.

NCBiR. "Program Innolot”. [In Polish: NCBiR. "Innolot Program”].

Oum, T.H., Yu, C., Fu, X. (2003). A comparative analysis of productivity performance of the world's major airports: summary report of the ATRS global airport benchmarking research report - 2002. Journal of Air Transport Management, 9 (5), p. 285-297.

Oum, T.H., Zhang, A., Zhang, Y. (2004). Alternative forms of economic regulation and their efficiency implications for airports. Journal of Transport Economics and Policy, 38 (2), p. 217-246.

Pavlyuk, D. (2009). Spatial competition pressure as a factor of European airports' efficiency. Transport and Telecommunication, 10 (4), p. 8-17.

Project Airport 2050+. "Final Report Summary - The 2050+ Airport”. Available at: http://www.2050airport. ineco.eu/2050airport/library/;ssessionid=65582DA732789CDB44971A4372E05054.nodo2.

Ray, S.C. (2004). Data Envelopment Analysis, Cambridge University Press, Cambridge. 
Rucińska, D. (2011). Badania rynku usług lotniczych. Istota, zakres, użyteczność, przykłady. Zeszyty naukowe, 9, Polskie Towarzystwo Ekonomiczne, Uniwersytet Gdański.

Ślusarczyk, B., Kot, S. (2015). Transport Effectiveness in Distribution of Steel Products, Applied Mechanics and Materials 718.

Steffen, J., Hotchkiss, J. (2012). Experimental test of airplane boarding methods. Journal of Air Transport Management, 18. 1: 64-67. ISSN: 0969-6997.

Szymajda, I. (2002). „Prawo lotnicze Unii Europejskiej - charakterystyka systemu. [Aviation Law European Union - characteristics of the system]. Studia Europejskie, 1 (21): 133-140. ISSN 1428-149X.

Tae Hoon, O., Chunyan, Y., Xiaowen, F. (2003). A comparative analysis of productivity performance of the world's major airports: summary report of the ATRS global airport benchmarking research report - 2002. Journal of Air Transport Management, 9, p. 285-297.

Takuma, H., Takeshi, T. (2010). "Formation Control of Small Unmanned Air Vehicles Under Faulty Communications. In AIAA Infotech@Aerospace: 3487. American Institute of Aeronautics and Astronautics, Atlanta, Georgia, USA. 20-22 April 2010.

Transport Research and Innovation Portal. "Air transport: Thematic Research Summary. Transport Research and Innovation Portal”. Available at: http://www.transport-research.info/Upload/Documen ts/201504/20150430_165104_74600_TRS12_fin.pdf.

ULC. (2013). Analiza rynku transportu lotniczego w 2012 roku w Polsce, Warszawa, Wydział statystyk i analiz.

ULC. (2014). Analiza przewozów pasażerskich w polskich portach lotniczych w 2013 roku, Warszawa, Wydział statystyk i analiz.

ULC. (2014a). 10 lat funkcjonowania zliberalizowanego rynku transport lotniczego po wejściu Polski do UE, Warszawa, Wydział statystyk i analiz.

Ustawa z dnia 3 lipca 2002 r. Prawo lotnicze, [Dz.U. 2002 Nr 130 poz. 1112].

Vogel, H.A. (2004). Airport Privatisation and Performance, PhD thesis, University of Westminster, School of Architecture and the Built Environment.

Westlake, J., Robbins, D. (2005). Transportation, [in:] C. Cooper, J. Fletcher, A. Fyall, D. Gilbert, S. Wanhill. (eds). Tourism: Principles and Practice, 3rd edition, Essex, Pearson Education Limited.

World Bank. (2011). The Air Connectivity Index: Measuring Integration in the Global Air Transport Network, Policy Research Paper 5722, June 2011, World Bank (online).

World Trade Organization. (2008). Liberalization of Air Transport Services and Passenger Traffic, Staff Working Paper ERSD-2008-06, December 2008.

\section{Lotnictwo cywilne w 2050 roku}

STRESZCZENIE Artykuł dotyczy opisu przyszłości lotnictwa cywilnego i jego obrazu w 2050 roku. Obejmuje m.in. opis gospodarki światowej, jej wpływu na rozwój lotnictwa cywilnego, opisuje przyszłych klientów i pasażerów lotniczych, ich preferencje, oczekiwania i priorytety. Znajduje się tutaj również opis przyszłych rozwiązań technologicznych samolotów, ich konstrukcji, napędów, możliwości technicznych i wyposażenia. W artykule poruszono również temat wpływu transportu lotniczego na ochronę środowiska oraz na inne powiązane branże z sektorem lotniczym.

SŁOWA KLUCZOWE innowacyjność, polityka transportowa, polityka lotnicza, port lotniczy, przyszłość samolotów 